\title{
Reorientasi Melalui Suara Keluarga Terhadap Tingkat Kesadaran Pada Pasien di Ruang ICU: Systematic Review
}

\author{
Wirda Y Dulahu ${ }^{1}$, Nurafni A. Mohamad ${ }^{2}$ \\ Program Studi Ilmu Keperawatan Universitas Negeri Gorontalo \\ Email : wirda@ung.ac.id
}

\begin{abstract}
Abstrak
Pendahuluan: Salah satu indikator kegawatdaruratan dan prognosis pada pasien kritis adalah status kesadaran dari pasien. Kehadiran dan interaksi keluarga dapat menjadi pilihan untuk membantu memperbaiki kondisi psikologis pasien ICU. Literatur Review ini bertujuan untuk mengetahui pengaruh reorientasi melalui suara keluarga terhadap tingkat kesadaran pada pasien di ruang ICU. Metode: Pencarian artikel menggunakan database Elsiver/Sciendirect, ProQuest, DOAJ, dan Google Scholar, dibatasi rentang 10 tahun terakhir; 2010 s/d 2020 didapatkan 12 jurnal. Hasil: Literatur yang didapat menyatakan bahwa pemberian intervensi berupa reorientasi melalui suara keluarga berpengaruh terhadap kesadaran pada pasien di ruang ICU. Melalui intervensi ini dapat meningkatkan tingkat kesadaran pasien yang menjalani perawatan di ruang ICU. Kesimpulan: Reorientasi melalui suara keluarga dapat diterapkan pada pasien dengan penurunan kesadaran di ruang ICU. Setelah mengetahui pengaruh reorientasi melalui suara keluarga bagi pasien, diharapkan dapat menjadi masukan dan acuan bagi rumah sakit dalam memberikan pelayanan keperawatan terhadap status kesadaran pasien di ruang ICU.
\end{abstract}

Kata kunci : Reorientasi suara keluarga, Pasien kritis

\begin{abstract}
Introduction: One of the indicators of emergency and prognosis in critical patients is the consciousness status of the patient. The presence and family interaction can be an option to help improve the psychological condition of ICU patients. This literature review aims to examine the effect of reorientation through family voices on the level of awareness of patients in the ICU. Methods: Search for articles using the Elsiver / Sciendirect, ProQuest, DOAJ, and Google Scholar databases, managing the last 10 years; 2010 s / d 2020 obtained 12 journals. Results: The literature shows that intervention instruction in the form of reorientation through family voices affects patient awareness in the ICU. This intervention can increase the level of awareness of patients undergoing treatment in the ICU. Conclusion: Reorientation through family voices can be applied to patients with decreased consciousness in the ICU. After the influence of reorientation through family voices for patients, it is hoped that it can become an input and reference for the hospital in providing nursing services to the patient's awareness status in the ICU.
\end{abstract}

Keywords: Reorientation of family voice, Critical patient

\section{Pendahuluan}

Data World Health Organization

(WHO) (2016), pasien kritis dengan penurunan kesadaran di ICU prevalensinya meningkat setiap tahunnya. Tercatat 9,824,6\% pasien sakit kritis dan dirawat di ICU per 100.000 penduduk, serta kematian akibat penyakit kritis hingga kronik di dunia meningkat sebanyak $1,1-7,4$ juta orang. Di ruangan ICU Rumah Sakit di negara-negara Asia termasuk Indonesia terdapat 1285 pasien kritis.

Salah satu indikator

kegawatdaruratan dan prognosis pada pasien kritis adalah status kesadaran dari pasien (Hudak dan Gallo, 2011). Dalam penanganan pasien dengan penurunan kesadaran dapat dilakukan dengan penanganan secara farmakologi melalui pemberian obat-obatan dan tindakan pembedahan, dimana intervensi ini akan 
didukung keberhasilanna melalui tindakan non farmakologi. Berbagai upaya asuhan keperawatan yang telah dikembangkan untuk membantu meningkatkan kesadaran pasien antara lain seperti pengaturan posisi, oksigenasi, stimulasi sensori, serta reorientasi melalui suara keluarga (Hutabarat dan Putra, 2014). Beberapa penelitian mengungkapkan penurunan kesadaran merupakan gambaran kondisi pada sebagian besar pasien kritis di ruang ICU dan salah satu tindakan yang direkomendasikan untuk mengatasi masalah ini yaitu berupa reorientasi melalui suara keluarga. Hal ini sejalan dengan penelitian yang dilakukan oleh Choirunnisa et all, (2019) bahwa pemberian rekaman pesan reorientasi menggunakan suara keluarga dapat menurunkan gejala delirium pada pasien di ruang ICU.

Reorientasi merupakan salah satu tindakan keperawatan yang dapat membantu memperbaiki kondisi psikologis pasien dengan penurunan kesadaran di ruang ICU. Intervensi ini dilakukan melalui rekaman suara keluarga yang berisi pengantar, menyebut nama pasien, tempat dan waktu, apa yang terjadi, dan beberapa kalimat tentang pemulihan serta motivasi untuk penyembuhan (Gorji et all, 2014). Reorientasi suara yang dilakukan keluarga lebih efektif dibandingkan menggunakan suara lainnya. Suara keluarga merupakan sebuah suara yang akrab bagi pasien karena keluarga merupakan orang-orang terdekat pasien sehingga melaui suara tersebut dapat menghasilkan perhatian yang lebih besar terhadap pasien dibandingkan dengan suara orang lain seperti suara perawat yang memberikan asuhan keperawatan di ruangan (Munro et all, 2017). Selain itu suara keluarga juga membuat pasien lebih merasa aman, nyaman dan terhibut serta memungkinkan mereka untuk menafsirkan dengan akurat rangsangan tersebut sehingga dapat berpengaruh terhadap tingkat kesadarannya (Trzepacz et all, 2010). Dengan intervensi tersebut akan membangkitkan aktivitas Reticular Activating System (RAS) yang dapat meningkatkan tingkat kesadaran dan fungsi kognitif sehingga akan membuat seseorang sadar terhadap diri dan lingkungannya (Choirunnisa et all, 2019). Untuk membuktikan efektifitas intervensi tersebut, perlu dilakukannya studi literature review terkait masalah ini.

Sehingga berdasarkan latar belakang tersebut, penelaah tertarik melakukan studi literature review mengenai pengaruh reorientasi melalui suara keluarga terhadap tingkat kesadaran pada pasien di ruang ICU. 
Vol. 2, No. 2, July, 2020

Dambura Nurisng Journal

pISSN: 2654-2927 eISSN: 2656-4653

Metode

Design yang digunakan adalah systematic review dari beberapa jurnal/artikel penelitian Randomize Controlled Trial (RCT) yang diterbitkan dari tahun 2010 sampai tahun 2020 yang membahas tentang reorientasi melalui suara keluarga terhadap tingkat kesadaran pada pasien yang mengalami penurunan kesadaran yang diyakini dapat menjawab peranyaan klinis penelitian yang telah dibuat sebelumnya. Adapun subjek penelitian adalah pasien yang mengalami penurunan kesadaran. Intervensi yang diberikan adalah reorientasi melalui suara keluarga untuk meningkatkan tingkat kesadaran pasien. Studi dikeluarkan apabila tidak menggunakan metode RCT (Rendomized Controlled Clinical Trials), artikel tidak full text, dan tidak menggunakan bahasa Indonesia/Inggris.

Penelusuran artikel/jurnal penelitian yang terpublikasi melalui database Elsiver/Sciendirect, ProQuest, DOAJ, dan Google Scholar. Kata kunci yang digunakan dalam pencarian artikel adalah reorientasi melalui suara keluarga, tingkat kesadaran, effect of family members' voice, level of consciousness.
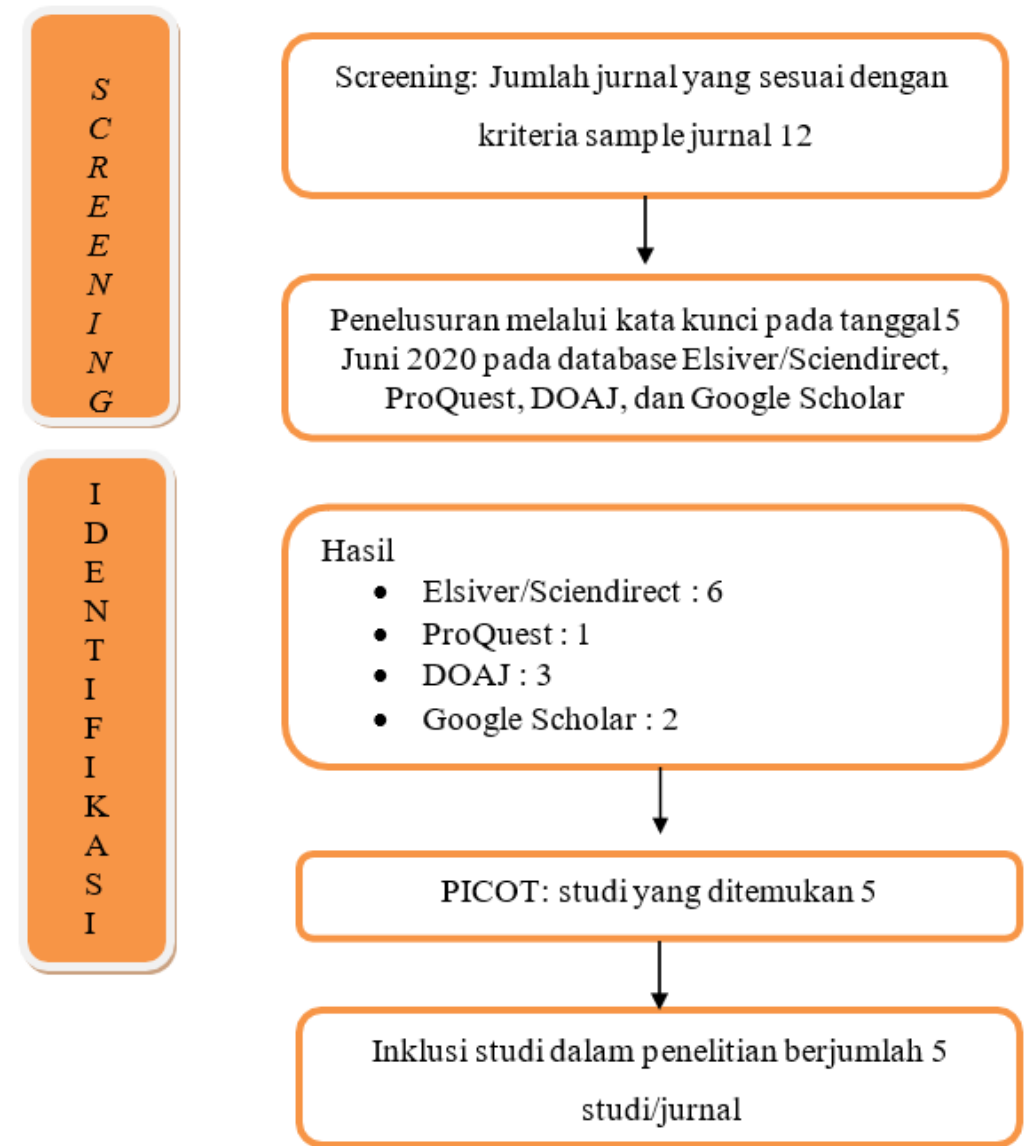

Gambar 1. Prisma Flow Chart 


\section{Hasil}

Dari 12 jurnal yang ditemukan hanya terdapat 5 jurnal yang digunakan dalam penelitian ini seluruh artikel menggunakan RCT (Rendomized Controlled Clinical Trials). Karakteristik pasien dengan penurunan kesadaran menjadi karakteristik utama, sedangkan untuk karakteristik intervensi dimasukan adalah reorientasi melalui suara keluarga.

Tabel 1. Ekstraksi Data

\begin{tabular}{|c|c|c|c|c|c|}
\hline $\begin{array}{c}\text { Studi } \\
\text { Author/Tahun }\end{array}$ & Tujuan & Sampel & Terapi & $\begin{array}{l}\text { Metode/Alat } \\
\text { Ukur }\end{array}$ & Outcome \\
\hline $\begin{array}{l}\text { Effect Of } \\
\text { Family } \\
\text { Members' Voice } \\
\text { On Level Of } \\
\text { Consciousness } \\
\text { Of Comatose } \\
\text { Patients } \\
\text { Admitted To } \\
\text { The Intensive } \\
\text { Care Unit } \\
\text { Tavangar, et all } \\
\text { / (2015) }\end{array}$ & $\begin{array}{l}\text { Untuk } \\
\text { mengetahui } \\
\text { pengaruh suara } \\
\text { anggota } \\
\text { keluarga pada } \\
\text { tingkat } \\
\text { kesadaran } \\
\text { pasien koma } \\
\text { yang dirawat di } \\
\text { ruang Intensive } \\
\text { Care Unit }\end{array}$ & $\begin{array}{lr}\text { Kelompok } & \\
\text { intervensi } & \\
\text { sebanyak } & 20 \\
\text { sampel } & \text { dan } \\
\text { kelompok } & \\
\text { kontrol } & \text { juga } \\
\text { sebanyak } & 20 \\
\text { sampel } & \end{array}$ & $\begin{array}{l}\text { Pada } \\
\text { kelompok } \\
\text { intervensi } \\
\text { diberikan } \\
\text { rekaman suara } \\
\text { dari anggota } \\
\text { keluarga } \\
\text { responden } \\
\text { melalui MP3 } \\
\text { selama } \\
\text { 5-15 menit, 2x } \\
\text { sehari dan } \\
\text { dilakukan } \\
\text { sampai } \\
\text { hari ke-10. } \\
\text { Sedangkan } \\
\text { pada kelompok } \\
\text { kontrol hanya } \\
\text { mendapatkan } \\
\text { perawatan dan } \\
\text { terapi yang } \\
\text { rutin } \\
\text { dilakukan di } \\
\text { ruangan, } \\
\text { tidak diberikan } \\
\text { intervensi } \\
\text { berupa suara } \\
\text { keluarga. }\end{array}$ & $\begin{array}{l}\text { RCT } \\
\text { (Rendomized } \\
\text { Controlled } \\
\text { Clinical Trials) } \\
\text { / GCS }\end{array}$ & $\begin{array}{l}\text { Berdasarkan } \\
\text { hasil penelitian } \\
\text { tersebut } \\
\text { menunjukkan } \\
\text { bahwa } \\
\text { rangsangan } \\
\text { suara yang } \\
\text { diberikan oleh } \\
\text { keluarga } \\
\text { memiliki } \\
\text { pengaruh } \\
\text { terhadap } \\
\text { peningkatan } \\
\text { kesadaran } \\
\text { pasien. Hal ini } \\
\text { yang } \\
\text { ditunjukkan dari } \\
\text { hasil perbedaan } \\
\text { nilai GCS pada } \\
\text { kelompok } \\
\text { kontrol dengan } \\
\text { kelompok } \\
\text { intervensi } \\
\text { dengan nilai } \\
\text { p-value } \\
=0,0001 \text { ) }\end{array}$ \\
\hline $\begin{array}{l}\text { Effect of } \\
\text { Auditory } \\
\text { Stimulation On } \\
\text { Traumatic } \\
\text { Coma Duration } \\
\text { In Intensive } \\
\text { Care Unit of } \\
\text { Medical } \\
\text { Sciences } \\
\text { University of } \\
\text { Mazandarn } \\
\text { Gorji, et all / } \\
\text { (2014) }\end{array}$ & $\begin{array}{l}\text { Untuk } \\
\text { menyelidiki } \\
\text { dampak suara } \\
\text { keluarga (yang } \\
\text { dikenal) } \\
\text { terhadap tingkat } \\
\text { kesadaran pada } \\
\text { pasien koma }\end{array}$ & $\begin{array}{l}\text { Jumlah sampel } \\
30 \text { yang terbagi } \\
\text { dalam } \\
\text { kelompok } \\
\text { kontrol dan } \\
\text { kelompok } \\
\text { intervensi, } \\
\text { masing- masing } \\
\text { terdiri dari } 15 \\
\text { sampel. }\end{array}$ & $\begin{array}{l}\text { Kelompok } \\
\text { eksperimen } \\
\text { diberikan } \\
\text { intervensi dua } \\
\text { kali sehari } \\
\text { setiap kali } 15 \\
\text { menit dengan } \\
\text { rekaman suara } \\
\text { keluarga yang } \\
\text { sudah dikenal } \\
\text { selama } 2 \\
\text { minggu. } \\
\text { Kelompok } \\
\text { kontrol tidak } \\
\text { diberikan } \\
\text { intervensi } \\
\text { yang sama } \\
\text { namun hanya } \\
\text { menerima } \\
\text { suara alami }\end{array}$ & $\begin{array}{l}\text { RCT } \\
\text { (Rendomized } \\
\text { Controlled } \\
\text { Clinical Trials) } \\
\text { / GCS }\end{array}$ & $\begin{array}{l}\text { Pemberian } \\
\text { intervensi } \\
\text { berupa } \\
\text { rekaman suara } \\
\text { kelurga (yang } \\
\text { dikenal) } \\
\text { effektif dalam } \\
\text { meningkatkan } \\
\text { tingkat } \\
\text { kesadaran } \\
\text { pasien cedera } \\
\text { kepala di } \\
\text { ruangan ICU. } \\
\text { Hasil } \\
\text { penelitian } \\
\text { menunjukkan } \\
\text { bahwa durasi } \\
\text { untuk } \\
\text { mencapai GCS } \\
=15\end{array}$ \\
\hline
\end{tabular}


Vol. 2, No. 2, July, 2020

\begin{tabular}{|c|c|c|c|c|c|}
\hline & & & $\begin{array}{l}\text { dari } \\
\text { lingkungan. }\end{array}$ & & $\begin{array}{l}\text { secara } \\
\text { signifikan } \\
\text { lebih pendek } \\
\text { pada } \\
\text { kelompok } \\
\text { eksperimen } \\
\text { dengan } \\
\text { dibandingkan } \\
\text { dengan } \\
\text { kelompok } \\
\text { kontrol, nilai } \\
\text { p-value } \\
\text { 0.001. }\end{array}$ \\
\hline $\begin{array}{l}\text { Delirium } \\
\text { Prevention In } \\
\text { Critically Ill } \\
\text { Adults Through } \\
\text { An } \\
\text { Automated } \\
\text { Reorientation } \\
\text { Intervention } \\
\text { Munro, et all } \\
\text { (2017) }\end{array}$ & $\begin{array}{l}\text { Untuk } \\
\text { menyelidiki } \\
\text { efek } \\
\text { intervensi } \\
\text { reorientasi } \\
\text { melalui suara } \\
\text { keluarga } \\
\text { terhadap } \\
\text { pengurangan } \\
\text { delirium }\end{array}$ & $\begin{array}{ll}\text { Kelompok } & \\
\text { intervensi } & \\
\text { sebanyak 10 } & \\
\text { orang dan } & \\
\text { kelompok } & \\
\text { kontrol } & \\
\text { sebanyak } & 10 \\
\text { orang } & \end{array}$ & $\begin{array}{l}\text { Pada kelompok } \\
\text { intervensi, } \\
\text { responden } \\
\text { menerima } \\
\text { pesan yang } \\
\text { direkam } \\
\text { berupa suara } \\
\text { anggota } \\
\text { keluarga } \\
\text { dengan durasi } \\
8 \text { jam } \\
\text { selama } 3 \text { hari, } \\
\text { sedangkan } \\
\text { pada kelompok } \\
\text { kontrol tidak } \\
\text { menerima } \\
\text { pesan } \\
\text { reorientasi } \\
\text { pesan suara } \\
\text { keluarga. }\end{array}$ & $\begin{array}{l}\text { RCT } \\
\text { (Rendomized } \\
\text { Controlled } \\
\text { Clinical Trials) } \\
\text { / CAM - ICU }\end{array}$ & $\begin{array}{l}\text { Reorientasi } \\
\text { melalui } \\
\text { pesan-pesan } \\
\text { otomatis dari } \\
\text { suara } \\
\text { keluarga } \\
\text { mengurangi } \\
\text { insiden } \\
\text { delirium. Hal } \\
\text { ini } \\
\text { berdasarkan } \\
\text { hasil } \\
\text { penelitian } \\
\text { yang } \\
\text { menyatakan } \\
\text { bahwa pada } \\
\text { setelah } \\
\text { pemberian } \\
\text { intervensi, } \\
\text { kejadian } \\
\text { delirium pada } \\
\text { kelompok } \\
\text { intervensi } \\
\text { yaitu menurun } \\
\text { drastis yaitu } \\
\text { dari 1,9\% } \\
\text { menjadi } 0,3 \% \text {, } \\
\text { sedangkan } \\
\text { pada kelompok } \\
\text { kontrol hanya } \\
\text { mengalami } \\
\text { sedikit } \\
\text { penurunan } \\
\text { yaitu dari } 1,6 \% \\
\text { menjadi } \\
0,9 \% \text {. } \\
\text { aha }\end{array}$ \\
\hline $\begin{array}{l}\text { The Effects of } \\
\text { Family } \\
\text { Centered } \\
\text { Affective } \\
\text { Stimulation on } \\
\text { Brain-Injured } \\
\text { Comatose } \\
\text { Patient's Level } \\
\text { of }\end{array}$ & $\begin{array}{l}\text { Untuk } \\
\text { mengevaluasi } \\
\text { efek stimulasi } \\
\text { afektif yang } \\
\text { berpusat pada } \\
\text { suara keluarga } \\
\text { terhadap } \\
\text { tingkat } \\
\text { kesadaran pada }\end{array}$ & $\begin{array}{l}\text { Kelompok } \\
\text { intervensi } \\
\text { sebanyak } 30 \\
\text { orang dan } \\
\text { kelompok } \\
\text { kontrol } \\
\text { sebanyak } 30 \\
\text { orang }\end{array}$ & $\begin{array}{l}\text { Intervensi } \\
\text { stimulasi } \\
\text { afektif melalui } \\
\text { suara anggota } \\
\text { keluarga } \\
\text { diberikan } \\
\text { kepada pasien } \\
\text { dalam } \\
\text { kelompok }\end{array}$ & $\begin{array}{l}\text { RCT } \\
\text { (Rendomized } \\
\text { Controlled } \\
\text { Clinical Trials) } \\
\text { / GCS }\end{array}$ & $\begin{array}{l}\text { Stimulasi } \\
\text { afektif yang } \\
\text { berpusat pada } \\
\text { suara keluarga } \\
\text { lebih efektif } \\
\text { daripada } \\
\text { stimulasi } \\
\text { sensorik } \\
\text { dalam }\end{array}$ \\
\hline
\end{tabular}


Vol. 2, No. 2, July, 2020

Dambura Nurisng Journal

pISSN: 2654-2927 eISSN: 2656-4653

\begin{tabular}{|c|c|c|c|c|c|}
\hline $\begin{array}{l}\text { Consciousness } \\
\text { Salmani, et all } \\
\text { / } 2017\end{array}$ & pasien koma & & $\begin{array}{l}\text { eksperimen } \\
\text { mereka dua } \\
\text { kali sehari } \\
\text { selama tujuh } \\
\text { hari. } \\
\text { Sedangkan } \\
\text { pasien dalam } \\
\text { kelompok } \\
\text { kontrol tidak } \\
\text { diberikan } \\
\text { intervensi } \\
\text { yang sama } \\
\text { namun hanya } \\
\text { menerima } \\
\text { stimulasi } \\
\text { sensorik yang } \\
\text { secara rutin } \\
\text { diberikan } \\
\text { kepada semua } \\
\text { pasien. }\end{array}$ & & $\begin{array}{l}\text { meningkatkan } \\
\text { tingkat } \\
\text { kesadaran pada } \\
\text { pasien koma } \\
\text { dengan cedera } \\
\text { otak, dengan } \\
\text { nilai } p \text {-value = } \\
0,001\end{array}$ \\
\hline $\begin{array}{l}\text { Implementasi } \\
\text { Reorientasi } \\
\text { Pasien } \\
\text { Delirium } \\
\text { Melalui } \\
\text { Rekaman } \\
\text { Suara } \\
\text { Keluarga di } \\
\text { Ruang ICU } \\
\text { RSUD Prof. } \\
\text { Dr. Margono } \\
\text { Soekarjo } \\
\\
\text { Choirunnisa, } \\
\text { et all / (2019) }\end{array}$ & $\begin{array}{l}\text { Untuk } \\
\text { mengetahui } \\
\text { pengaruh } \\
\text { implementasi } \\
\text { reorientasi } \\
\text { melalui } \\
\text { rekaman suara } \\
\text { anggota } \\
\text { keluarga } \\
\text { tingkat } \\
\text { kesadaran pada } \\
\text { pasien } \\
\text { delirium }\end{array}$ & $\begin{array}{l}\text { Sampel dibagi } \\
\text { menjadi } 2 \\
\text { kelompok } \\
\text { yaitu, } \\
\text { kelompok } \\
\text { intervensi dan } \\
\text { kelompok } \\
\text { kontrol yang } \\
\text { masing- } \\
\text { masing } \\
\text { kelompok } \\
\text { sebanyak } 2 \\
\text { pasien. }\end{array}$ & $\begin{array}{l}\text { Rekaman } \\
\text { suara keluarga } \\
\text { akan diberikan } \\
\text { selama } 8 \text { jam } \\
\text { perhari selama } \\
2 \text { hari. } \\
\text { Sedangkan } \\
\text { pada } \\
\text { kelompok } \\
\text { kontrol tidak } \\
\text { diberikan } \\
\text { intervensi } \\
\text { yang sama } \\
\text { namun hanya } \\
\text { mendapatkan } \\
\text { terapi standar } \\
\text { dengan } \\
\text { pemberian } \\
\text { komunikasi } \\
\text { terapeutik dari } \\
\text { perawat. }\end{array}$ & $\begin{array}{l}\text { RCT } \\
\text { (Rendomized } \\
\text { Controlled } \\
\text { Clinical Trials) } \\
\text { / RASS }\end{array}$ & $\begin{array}{l}\text { Hasil } \\
\text { penelitian } \\
\text { menunjukkan } \\
\text { bahwa } \\
\text { pemberian } \\
\text { rekaman pesan } \\
\text { reorientasi } \\
\text { menggunakan } \\
\text { suara keluarga } \\
\text { dapat } \\
\text { menurunkan } \\
\text { gejala delirium } \\
\text { pada pasien di } \\
\text { ruang ICU hal } \\
\text { ini didasarkan } \\
\text { pada hasil } \\
\text { penurunan } \\
\text { skor RASS } \\
\text { pada } \\
\text { kelompok } \\
\text { intervensi } \\
\text { suara } \\
\text { keluarga. } \\
\text { Sedangkan } \\
\text { pada } \\
\text { kelompok } \\
\text { kontrol tidak } \\
\text { mengalami } \\
\text { perubahan }\end{array}$ \\
\hline
\end{tabular}

\section{Pembahasan}

Penurunan kesadaran merupakan

gambaran kondisi pada sebagian besar

pasien kritis di ruang ICU. Salah satu

bagian ruang lingkup pelayanan ICU adalah memberikan bantuan psikologis

pada pasien dan keluarga yang

kehidupannya sangat bergantung pada

obat, alat, dan mesin (KEMENKES RI,

2012). Reorientasi merupakan salah satu 
tindakan keperawatan yang dapat membantu memperbaiki kondisi psikologis pasien dengan penurunan kesadaran di ruang ICU. Kehadiran dan interaksi keluarga dapat menjadi pilihan untuk membantu memperbaiki kondisi psikologis pasien ICU terutama mereka yang terpasang peralatan khusus seperti ventilator mekanik (Munro et al, 2017). Intervensi ini dilakukan melalui rekaman suara keluarga yang berisi pengantar, menyebut nama pasien, tempat dan waktu, apa yang terjadi, dan beberapa kalimat tentang pemulihan serta motivasi untuk penyembuhan (Gorji, et all., 2014).

Reorientasi suara yang dilakukan keluarga lebih efektif dibandingkan menggunakan suara lainnya. Suara keluarga merupakan sebuah suara yang akrab bagi pasien karena keluarga merupakan orang-orang terdekat pasien sehingga melaui suara tersebut dapat menghasilkan perhatian yang lebih besar terhadap pasien dibandingkan dengan suara orang lain seperti suara perawat yang memberikan asuhan keperawatan di ruangan. Selain itu suara keluarga juga membuat pasien lebih merasa aman, nyaman dan terhibut serta memungkinkan mereka untuk menafsirkan dengan akurat rangsangan tersebut sehingga dapat berpengaruh terhadap tingkat kesadarannya (Trzepacz, et al, 2010).
Sehingga untuk membuktikan efektifitas intervensi tersebut penulis melakukan studi literature review dan mendapatkan 5 jurnal yang terdiri dari 1 jurnal nasional dan 4 jurnal internasional. Dari kelima jurnal tersebut menghasilkan suatu kesimpulan yang menyatakan bahwa ada pengaruh reorientasi melalui suara keluarga terhadap peningkatan tingkat kesadaran pasien. Kelima jurnal tersebut menghasilkan kesimpulan yang sama namun masing-masing memiliki cara penelitian yang berbeda dilihat dari jumlah dan karakteristik respondenya, dan waktu/perlakuan pemberian intervensi.

Dari segi responden yang diteliti, kelima jurnal mengambil responden yang sama yaitu pasien yang mengalami penurunan kesadaran. Namun, kelima jurnal ini mengambil jumlah dan karakteristik responden yang berbeda. Berdasarkan Jurnal Tavangar et all, responden yang digunakan berjumlah 20 orang dalam kelompok intervensi dan 20 orang dalam kelompok kontrol, dengan karakterisktik pasien koma yang dikarenakan adanya hematoma subdural akut. Pada Jurnal Gorji et all, jumlah sampel yang digunakan adalah 30 yang terbagi dalam kelompok kontrol dan kelompok intervensi, masing-masing terdiri dari 15 sampel, dengan kriteria responden berupa pasien koma yang 
diakibatkan adanya trauma. Jurnal Salmani et all, menggunakan responden sebanyak 30 orang di setiap kelompok dengan kriteria responden pasien koma yang dikarenakan cedera otak. Sedangkan jurnal Munro et all, serta jurnal Choirunnisa et all, menggunakan responden dengan karakteristik yang sama yaitu pasien delirium, namun dengan jumlah responden yang berbeda yaitu 10 responden setiap kelompok untuk jurnal Munro et all, dan jurnal Choirunnisa et all, hanya menggunakan 2 responden setiap kelompok.

Penelitian kelima jurnal ini memiliki cara penelitian sama yaitu memberikan intervensi berupa reorientasi melalui suara keluarga pada pasien dengan penurunan kesadaran sebagai responden. Namun, kelima jurnal ini menerapkan waktu pemberian intervensi yang berbedabeda. Pada jurnal Tavangar et all, menerapkan intervensi selama 5-15 menit, 2x sehari dan dilakukan sampai hari ke-10. Jurnal Gorji et all, menerapkan intervensi dengan durasi 15 menit, 2x sehari selama 2 minggu atau 14 hari. Sedangkan jurnal Munro et all dan jurnal Choirunnisa et all,, menerapkan durasi waktu pemberian intervensi yang sama yaitu 8 jam dengan rentang waktu yang berbeda, dimana untuk jurnal Munro et all diterapkan selama 3 hari dan untuk Choirunnisa et 11 hanya diterapkan selama 2 hari saja. Berbeda halnya dengan jurnal Salmani et all yang dalam penelitiannya menerapkan intervensi $2 \mathrm{x}$ sehari selama 7 hari namun dalam jurnalnya tidak memaparkan durasi waktu pelaksanaan berapa menit untuk pelaksanaan 1x intervensi. Interval waktu pelaksanaan intervensi ini yaitu diantara pukul 9:00 pagi dan berakhir pada pukul 4:00 sore.

Kelima jurnal ini mempunyai hasil yang sama yaitu pemberian reorientasi melalui suara keluarga dapat meningkatkan tingkat kesadaran pasien. Pada jurnal Tavangar et all, yang meneliti tentang pengaruh suara anggota keluarga pada tingkat kesadaran pasien koma yang dirawat di ruang Intensive Care Unit, hasil penelitian menunjukkan bahwa pada kelompok intervensi rata-rata nilai GCS saat pre test yaitu 6,25 dan post test meningkat menjadi 10,25 (meningkat 4). Sedangkan pada kelompok kontrol ratarata nilai GCS saat pre test yaitu 6,30 dan post test hanya meningkat menjadi 7,75 (meningkat 1,45). Sehingga dapat disimpulkan bahwa rangsangan suara yang diberikan oleh keluarga memiliki pengaruh terhadap peningkatan kesadaran pasien. Hal ini yang ditunjukkan dari hasil perbedaan nilai GCS pada kelompok kontrol dengan kelompok intervensi dengan nilai $\mathrm{p}$-value $=0,0001$ ) 
Bedasarkan Jurnal Gorji et all, yang meneliti tentang efek suara keluarga (yang dikenal) terhadap tingkat kesadaran pada pasien koma, hasil penelitian menunjukkan bahwa pemberian intervensi berupa rekaman suara kelurga (yang dikenal) effektif dalam meningkatkan tingkat kesadaran pasien cedera kepala di ruangan ICU. Hasil penelitian menunjukkan bahwa durasi untuk mencapai GCS = 15 secara signifikan lebih pendek pada kelompok eksperimen dengan dibandingkan dengan kelompok kontrol, dengan nilai p-value 0.001 . Dimana untuk kelompok intervensi hanya memerlukan waktu singkat untuk mencapai GCS $=15$ yaitu rata-rata hanya 6,46 hari. Sedangkan untuk kelompok kontrol memerlukan waktu yang lama yaitu rata-rata 12,26 hari. Dalam penelitian ini hanya melihat durasi perbandingan waktu dari responden untuk mencapai tingkat GCS normal yaitu 15, tidak memberikan hasil perbedaan antara skor awal (pre test) dan skor akhir (post test) dari nilai GCS.

Jurnal Munro et all, yang meneliti tentang efek intervensi reorientasi melalui suara keluarga terhadap pengurangan delirium juga mendapatkan hasil yang sama. Dalam penelitiannya menghasilkan bahwa setelah pemberian intervensi, kejadian delirium pada kelompok intervensi yaitu menurun drastis yaitu dari $1,9 \%$ menjadi $0,3 \%$ (menurun 1,6), sedangkan pada kelompok kontrol hanya mengalami sedikit penurunan yaitu dari $1,6 \%$ menjadi $0,9 \%$ (menurun 0,7 ). Sehingga dapat disimpulkan bahwa reorientasi melalui pesan-pesan otomatis dari suara keluarga mengurangi insiden delirium. Pada jurnal nasional oleh Choirunnisa et all juga menghasilkan penelitian yang sama bahwa bahwa pemberian rekaman pesan reorientasi menggunakan suara keluarga dapat menurunkan gejala delirium pada pasien di ruang ICU hal ini didasarkan pada hasil penurunan skor RASS pada kelompok intervensi suara keluarga. Sedangkan pada kelompok kontrol tidak mengalami perubahan.

Sama halnya dengan jurnal internasional terakhir oleh Salmani et all, yang dimana dalam penelitian ini mengevaluasi efek stimulasi afektif yang berpusat pada suara keluarga terhadap tingkat kesadaran pada pasien koma dan mendapatkan hasil bahwa pada kelompok intervensi rata-rata nilai GCS saat pre test yaitu 5,3 dan post test meningkat menjadi 9,1 (meningkat 3,8). Sedangkan pada kelompok kontrol rata-rata nilai GCS saat pre test yaitu 5,3 dan post test hanya meningkat menjadi 6,6 (meningkat 1,3 ). Sehingga dapat disimpulkan bahwa 
stimulasi afektif yang berpusat pada suara

keluarga lebih efektif daripada stimulasi sensorik dalam meningkatkan tingkat kesadaran pada pasien koma, dengan nilai $\mathrm{p}$-value $=0,001$.

Kelima jurnal penelitian yang di review baik jurnal nasional maupun jurnal internasional semuanya mengungkapkan hasil yang sama yang menyatakan bahwa reorientasi melalui suara keluarga memberi pengaruh terhadap peningkatan tingkat kesadaran pada pasien di ruang ICU. Tingkat kesadaran itu sendiri ditentukan oleh banyaknya neuron penggerak atau neuron pengemban kewaspadaan yang aktif. Unsur fungsional utama neuron-neuron ialah kemampuan untuk dapat digalakkan sehingga menimbulkan potensial aksi. Selain itu, juga didukung oleh proses-proses yang menjaga neuron-neuron serta unsur- unsur selular otak melalui proses biokimiawi, karena tingkat kesadaran bergantung pada jumlah neuron-neuron yang aktif. Adanya gangguan baik pada neuron-neuron pengemban kewaspadaan ataupun penggerak kewaspadaan akan menimbulkan gangguan kesadaran (Smeltzer \& Bare, 2013).

Pada pasien dengan penurunan kesadaran sistem pendengaran merupakan indera terakhir yang berfungsi sehingga memberikan reorientasi melalui suara anggota keluarga menjadi salah satu intervensi yang efisien untuk dilakukan. Menurut Trzepacz et all (2010), memberikan intervensi ini dengan intensitas dan durasi yang sering dapat meningkatkan organisasi neuronal, memfasilitasi baik pertumbuhan dendrit dan meningkatkan konektivitas sinaptik pada system saraf yang rusak dan akhirnya dapat meningkatkan level dari fungsi kognitif. Selain itu memberikan reorientasi melalui suara anggota keluarga akan membangkitkan aktivitas Reticular Activating System (RAS) yang dapat meningkatkan tingkat kesadaran dan fungsi kognitif sehingga akan membuat seseorang sadar terhadap diri dan lingkungannya. Reorientasi yang dilakukan orang-orang terdekat pasien seperti keluarga juga akan membuat pasien lebih merasa aman dan nyaman.

\section{Daftar Pustaka}

Choirunnisa, D, et all. (2019). Implementasi Reorientasi Pasien Delirium Melalui Rekaman Suara Keluarga di Ruang ICU RSUD Prof. Dr. Margono Soekarjo. Journal of Bionursing, 1(2), 133-141.

Gattinoni, L., \& Carlesso, E. (2013). Supporting hemodynamics: What should we target? What treatments should we use. Critical Care, 17(1), 73-81.

Gorji, M.A.H, et all. (2014). Effect of Auditory Stimulation On Traumatic Coma Duration In Intensive Care Unit of Medical Sciences University of Mazandarn. Saudi Journal of 
Anesthesia, 8(1), 69-72.

Hutabarat, R.Y. dan Putra, C.S. (2014). Asuhan Keperawatan Kegatdaruratan. Bogor: IN MEDIA.

KEMENKES RI. (2012). Pedoman Teknis Bangunan Rumah Sakit Ruang Perawatan Intensif. Jakarta: Direktorat Bina Pelayanan Penunjang Medik dan Sarana Kesehatan.

KEPMENKES. (2010). Pedoman Penyelenggaraan Pelayanan Intensive Care Unit (ICU) di Rumah Sakit. Nomor:1778/Menkes/SK/XII/2010. Jakarta: Direktur Jenderal Bina Upaya Kesehatan.

Marton, P.C. dkk. (2011). Keperawatan Kritis Pendekatan Asuhan Holistik Volume 1 Edisi 8. Jakarta: EGC.

Munro, C. L., et all. (2017). Delirium Prevention In Critically Ill Adults Through An Automated Reorientation Intervention. The Journal of Heart and Lung, 30 (4), 1-5.

Musliha. (2010). Keperawatan Gawat Darurat Plus Contoh Askep dengan Pendekatan NANDA, NIC, NOC. Yogyakarta: Nuha Medika.

PERMENKES. (2016). Persyaratan Teknis Bangunan dan Prasarana Rumah Sakit. Nomor 24 tahun 2016.
Jakarta: Direktur Jenderal Bina Upaya Kesehatan.

Perry A.G. dan P.A. Potter. (2010). Fundamental Keperawatan Buku 3 Edisi 7. Jakarta: Salemba Medika. Salmani, F., et all. (2017). The Effects of Family Centered Affective Stimulation on Brain-Injured Comatose Patient's Level of Consciousness. International Journal of Nursing Studies, 74(1), 44-52.

Smeltzer, S.C. dan Bare B.G. (2013). Buku Ajar Keperawatan Medikal Bedah Brunner \& Suddarth Edisi 8 Volume 3. Jakarta : EGC.

Sugiono, (2013). Metodologi Penelitian Pendidikan Pendekatan Kuantitatif, Kualitatif dan $R \& D$. Bandung: Alfabeta.

Tavangar, H, et all. (2015). Effect Of Family Members' Voice On Level Of Consciousness Of Comatose Patients Admitted To The Intensive Care Unit. Advanced Biomedical Research. 4(1), 106-106.

Trzepacz, P., et al. (2010). Practice Guideline for The Treatment of Patients With Delirium. Journal American Phychiatric Association, 2(1), 31-39.

World Health Organization. (2016). World Health Statistic 2015. USA WHO 